\title{
KONTRIBUSI REMITANSI PEREMPUAN TERHADAP RUMAH TANGGA PETANI DI KABUPATEN INDRAMAYU
}

\section{CONTRIBUTION OF WOMEN REMITTANCE TOWARD FARMERS HOUSEHOLD IN INDRAMAYU RESIDENCE}

\author{
Risnawati*, Ahmad Choibar Tridakusumah \\ Fakultas Pertanian Universitas Padjadjaran, Jalan Raya Bandung-Sumedang \\ *E-mail: risnawati16001@mail.unpad.ac.id \\ (Diterima 14-01-2020; Disetujui 20-01-2020)
}

\begin{abstract}
ABSTRAK
Bekerja sebagai pekerja migran merupakan salah satu alternatif perempuan pedesaan untuk mempertahankan penghidupan rumah tangga pertaniannya. Kabupaten Indramayu merupakan penyumbang pekerja migran perempuan terbanyak kedua di Indonesia dan berkontribusi terhadap rumah tangga migran di daerah asal melalui remitansi sosial atau ekonomi. Secara ekonomi dapat berkontribusi pada rumah tangga migran, salah satunya digunakan untuk investasi pertanian. Tujuan dari penelitian ini adalah menganalisis kontribusi remitansi untuk investasi pertanian. Penelitian ini merupakan penelitian studi kasus yang menggunakan teknik kualitatif. Pemilihan informan menggunakan teknik snowball dan melalui wawancara mendalam. Hasil penelitian ini memperlihatkan bahwa kondisi rumah tangga petani tidak dapat terpenuhi hanya dari kegiatan pertanian dan nelayan (on-farm, off-farm, dan non-farm). Menjadi pekerja migran perempuan sudah menjadi budaya masyarakat desa dikarenakan banyaknya remitansi yang diterima menjadikan perekonomian rumah tangga migran dapat mencukupi kebutuhan. Remitansi dipergunakan oleh rumah tangga migran untuk investasi pertanian, seperti pembelian perahu dan pembelian lahan pertanian.
\end{abstract}

Kata kunci: Remitansi, Rumah Tangga Pertanian, Investasi, Pekerja Migran Perempuan

\section{ABSTRACT}

Working as a migrant worker is one alternative for rural women to maintain the livelihoods of their agricultural households. Indramayu District is the second-largest contributor of female migrant workers in Indonesia and contributes to migrant households in the area of origin through social or economic remittances. Economically it can contribute to migrant households, one of which is used for agricultural investment. The purpose of this study is to analyze the contribution of remittances to agricultural investment. This research is a case study research using qualitative techniques. The selection of informants uses snowball techniques and through in-depth interviews. The results of this study indicate that the farmer's household conditions cannot be fulfilled only from agricultural and fishing activities (on-farm, off-farm, and non-farm). Being a female migrant worker has become a culture of rural communities because of the large number of remittances received making the migrant household's economy meet its needs. Remittances are used by migrant households for agricultural investment, such as boat purchases and agricultural land purchases.

Keywords: Remittances, Household Agriculture, Investment, Women Migrant Workers 


\section{PENDAHULUAN}

Secara umum migrasi dibagi menjadi dua yaitu Migrasi Internal dan Migrasi Internasional. Migrasi internasional merupakan perpindahan penduduk dari suatu negara ke negara lain. Pekerja migran tersebut berasal dari berbagai daerah di Indonesia, salah satunya adalah Jawa Barat sebagai asal pekerja migran terbanyak ketiga di Indonesia. Berdasarkan data Jumlah pekerja migran Indonesia dari Provinsi Jawa Barat pada tahun 2017 sebanyak 50.844 orang (BNP2TKI, 2018). Data tersebut terdiri dari 8.620 pekerja migran laki-laki dan 42.224 pekerja migran perempuan. Pada tahun 2018 jumlah pekerja migran asal Jawa Barat mengalami peningkatan yaitu 57.230 orang terdiri dari 9.455 pekerja migran laki-laki dan 47.755 pekerja migran perempuan (BNP2TKI, 2018). Hal tesebut memperlihatkan Jawa Barat masih menempati posisi provinsi terbesar ketiga penyumbang pekerja migran dan meningkatnya jumlah pekerja migran perempuan.

Kabupaten Indramayu Jawa Barat, merupakan penyumbang pekerja migran terbanyak pertama menurut (BNP2TKI 2018). Hal tersebut didukung dengan data Jumlah pekerja migran Indonesia dari
Indramayu sebanyak 17.658 pada tahun 2017, meningkat pada tahun 2018 sebanyak 22.144 pekerja migran (BNP2TKI, 2018). Pekerja migran memberikan kontribusi bagi negara asalnya berupa remitansi ekonomi (uang) dan sosial (ide, keahlian, gagasan, dan pengalaman). Jumlah remitansi ekonomi berbanding lurus dengan jumlah pekerja migran yang cenderung meningkat. Remitansi menyumbang 1\% dari PDB Indonesia, yaitu pada tahun 2016 sebesar 118 triliun. ${ }^{1}$

Salah satu kecamatan di Indramayu yang menjadi penyumbang pekerja migran Indonesia terbanyak adalah Kecamatan Juntinyuat. Tahun 2017 luas wilayah Kecamatan Juntinyuat yaitu $50,83 \mathrm{Km}^{2}$ (BPS Indramyu, 2018). Jumlah penduduk di Kecamatan Juntinyuat pada tahun 2017 yaitu sebanyak 76.752 jiwa terdiri dari laki-laki 40.386 dan 36.370 penduduk perempuan. Berdasarkan data badan pusat statistik tahun 2017 pekerja migran yang berasal dari kecamatan Juntinyuat sebanyak 6.686. Terdiri dari 297 pekerja migran laki-laki dan 6.389 pekerja migran

\footnotetext{
${ }^{1}$ Diakses dari

https://www.cnnindonesia.com/ekonomi/2017112 8114247-78-258562/bank-dunia-remitansi-tkitembus-rp118-triliun pada 12 Januari 2020, pukul 01.10 WIB.
} 
perempuan (BPS Juntinyuat dalam Angka 2018).

Pekerja migran Indonesia di Kecamatan Juntinyuat, mungkin kurang lengkap apabila tidak membahas mengenai Desa Dadap yang terletak di Kecamatan Juntinyuat. Desa tersebut penduduknya terdiri dari laki-laki 6.912 dan perempuan berjumlah 6.262 (BPS, 2018). Berdasarkan data dari BPS Desa Dadap merupakan penyumbang terbanyak pekerja migran Indonesia. Hal tersebut dapat dilihat dari jumlah penduduk yang menjadi Pekerja migran perempuan dari Desa Dadap tahun 2017 sebanyak 1.549, terdiri dari pekerja migran laki-laki 48 dan pekerja migran perempuan sebanyak 1.501 (BPS, 2018). Data tersebut menegaskan bahwa Desa Dadap merupakan penyumbang Pekerja migran perempuan terbanyak.

Jumlah pekerja migran berbanding terbalik dengan jumlah petani yang ada di Desa Dadap. Jumlah Petani Pemilik, Penggarap dan Buruh Tani di Desa Dadap pada tahun 2017 sebanyak 292 (BPS, 2018). Jumlah Petani di Desa dadap merupakan yang paling sedikit diantara desa lainnya di Kecamatan Juntinyuat. Jumlah rumah tangga pertanian di Desa Dadap lebih tinggi dibandingkan jumlah Petani Pemilik,
Penggarap dan Buruh Tani. Pengertian rumah tangga pertanian menurut BPS yaitu rumah tangga yang sekurang kurangnya terdapat satu anggota rumah tangga yang melakukan kegiatan yang bisa menghasilkan produk pertanian serta memiliki tujuan untuk dijual memperoleh pendapatan atas resiko sendiri. Kegiatan tersebut dapat meliputi berkebun atau bertani, beternak ikan dikolam maupun tambak, nelayan dan berternak unggas. Desa Dadap pada tahun 2017 terdapat 628 rumah tangga pertanian (BPS, 2018).

Kehidupan penduduk perempuan (istri) di Desa Dadap banyak yang menjadi pekerja migran, namun sebagian besar penduduk laki-lakinya (suami) bermata pencaharian sebagai nelayan, wirausahawan dan petani. Namun, terdapat permasalahan pertanian di Desa Dadap yaitu sebagian besar pertaniannya hanya bertumpu pada komoditas padi yang hanya dua kali musim panen, tidak adanya saluran irigasi, kemarau berkepanjang, serta alih fungsi lahan pertanian menjadi pemukiman. Ketika musim panen padi telah selesai, maka petani tidak menanam komoditas lain di lahan miliknya. Petani hanya menunggu sampai musim tanam padi berikutnya. Akibat dari hal tersebut banyak petani yang menganggur dan terpaksa berhutang 
untuk memenuhi kebutuhan hidup seharihari. Pendapatan suami apabila tidak mencukupi dari hasil bertani, maka istrinya bekerja sebagai pekerja migran perempuan. Sebagaimana pernyataan mengenai peralihan bekerja dari sektor pertanian kepada sektor lain disebabkan tidak mencukupinya pendapatan di sektor pertanian, bersifat musiman, dan banyak mengandung resiko dan ketidakpastian (Mubyarto, 1985 dalam Mukbar 2009 dalam Irawanty et al. 2011). Setidaknya yang terjadi di Desa Dadap tercermin pada penelitian di Kecamatan Lawongan Utara tahun 2013 dari 34 responden pekerja migran yang bekerja di luar negeri sebanyak $35,2 \%$ sebelumnya berprofesi sebagai petani (Rantung, 2018).

Kehidupan masyarakat Desa Dadap tidak tidak terlepas dari sumber nafkah baik sebagai petani maupuan sebagai nelayan, karena letak geografis Desa Dadap dekat dengan pesisir. Permasalahan yang dialami nelayan disebabkan oleh keadaan alam dan hasil tangkapan di lautan yang tidak menentu. Akibatnya banyak nelayan mengangur dan mendesak mereka harus berhutang untuk memenuhi kebutuhan hidup seharihari. Realita tersebut mendorong istri para nelayan untuk menjadi pekerja migran, demi membantu perekonomian rumah tangganya.

Kontribusi pekerja migran perempuan terhadap rumah tangga petani adalah remitansi. Remitansi tersebut bisa dalam bentuk ekonomi yaitu uang ataupun dalam bentuk sosial berupa pengetahuan, ide atau keterampilan. Faktanya, remitansi di Desa Dadap lebih banyak dalam bentuk pengiriman uang kepada rumah tangga migran di daerah asal. Penggunaan remitan bagi rumah tangga di Desa Dadap masih belum bisa digunakan secara optimal oleh rumah tangga tersebut. Hal tersebut sejalan dengan pernyataan mengenai uang remitan biasanya tidak dipergunakan untuk investasi ke lahan pertanian, namun untuk kebutuhan konsumtif (Forbes, 1986 dalam effendi, 2004 dalam Irawaty, 2011). Bertolak belakang dengan pernyataan dari Forbes, adanya penelitian yang berbeda di Gunung Kidul bahwa penggunaan remitan tidak hanya untuk kebutuhan konsumtif, tapi diinvestasikan dalam jangka panjang seperti meningkatkan produksi pertanian (Hadisupdmo, 1991 dalam Murdiyanto, 2001 Irawaty, 2011). Hal tersebut terjadi juga di Desa Dadap, penggunaan remitansi terhadap investasi pertanian sudah dilakukan di Desa Dadap. Namun, 
hanya beberapa petani yang melakukan hal tersebut, dikarenakan banyaknya pemanfaatan remitansi untuk memenuhi kebutuhan hidup sehari-hari serta membayar hutang.

Remitansi dapat berpeluang untuk mengurangi kemiskinan serta pemanfaat remitansi tergantung dari jumlah remitansi yang diterima oleh setiap pekerja migran. Oleh sebab itu, remitansi dari pekerja migran Indonesia kepada rumah tangga di daerah asal menjadi suatu aspek penting yang berperan untuk meningkatkan taraf hidup rumah tangga yang ditinggalkan serta dapat meningkatkan pendapatan. Seperti yang sudah dijelaskan sebelumnya, kesepakatan ketenagakerjaan antar negara akan meningkatkan terjadinya pendapatan sebagai implikasi langsung dari besarnya remitan dan besarnya jumlah imigrasi (Edi Sutanto, 2004 Rantung, 2018). Adanya peningkatan pendapatan rumah tangga migran akibat remitansi. Namun penggunaannya lebih banyak untuk memenuhi kebutuhan hidup, membangun rumah, pendidikan anak, dan membeli perhiasan (emas). Hanya beberapa petani yang menginvestasikan kedalam pertanian, misalnya untuk pembelian lahan pesawahan. Awalnya buruh tani atau petani penggarap melakukan gadai sawah, kemudian sawah yang digadai bisa terbeli, sehingga status mereka berubah menjadi petani diakibatkan memiliki lahan pertanian. Oleh karena itu, remitansi tidak bisa dijadikan sebagai penghasilan utama, tetapi sebagai modal pendukung untuk memperluas dan meningkatkan investasi pertaniannya. Pemanfaatan remitansi oleh petani, buruh tani, petani penggarap, dan nelayan berbeda tergantung dari prioritas serta cita-cita rumah tangga petani. Berdasarkan uraian diatas maka penelitian ini menarik untuk dapat mengetahui lebih lanjut mengenai kontribusi remitansi istri petani pada investasi rumah tangga.

\section{METODE PENELITIAN}

Objek yang menjadi bahan penelitian adalah kontribusi remitansi pada rumah tangga petani. Hal ini akan ditinjau dari bagaimana penggunaan remitansi yang digunakan oleh rumah tangga migran untuk pemanfaatannya dibidang pertanian secara luas. Sedangkan subjek dalam penelitian ini merupakan rumah tangga petani yang menerima uang remitansi serta pekerja migran perempuan migran yang sudah kembali ke daerah asalnya. Dalam 
penelitian ini beberapa analisis yang digunakan ada tiga teknik yaitu reduksi data, penyajian data, dan penarikan kesimpulan (Miles dan Huberman, 1992). Metode penelitian yang dipergunakan dengan kaidah Triangulasi, teknik pemeriksaan keabsahan data yang memanfaatkan sesuatu yang lain, diluar data tersebut untuk keperluan pengecekan atau sebagai pembanding terhadap data itu (Moleong, 2017).

Pemilihan lokasi dilakukan berdasarkan data yang didapatkan dari sumber BPS bahwa daerah di Indramayu merupakan penyumbang tenaga kerja migran terbanyak kedua di Indonesia. Kecamatan Juntinyuat terutama di Desa Dadap merupakan penyumbang tenaga kerja migran terbanyak yang berasal dari Indramayu. Pada tahun 2017 sebanyak 1.501 perempuan di Desa Dadap yang menjadi pekerja migran sedangkan tenaga kerja laki-laki sebanyak 48 orang yang menjadi pekerja migran (BPS, 2018). Berdasarkan data tersebut maka Desa Dadap menjadi penyumbang terbesar pekerja migran di Kecamatan Juntinyuat.

Data yang didapatkan untuk penelitian ini berasal dari data primer dan data sekunder. Data primer merupakan data yang diperoleh langsung dari lokasi penelitian dengan wawancara mendalam yang dilakukan oleh penulis terhadap rumah tangga migran pertanian, dan pekerja migran perempuan yang sudah kembali ke daerah asal. Informan dalam penelitian ini berjumlah dua orang yang bermata pencaharian sebagai nelayan (AR) dan petani (AD), dengan syarat melakukan investasi pertanian menggunakan uang remitansi dari istri yang bekerja sebagai pekerja migran perempuan.

\section{HASIL DAN PEMBAHASAN}

Remitansi yang berasal dari pekerja migran perempuan dimanfaatkan oleh rumah tangga petanian khususnya bagi petani ketika sudah membangun rumah, kehidupan sehari-hari, dan membiayai sekolah anak, maka uang tersebut oleh sebagian petani dipergunakan untuk mengadai sawah. tentunya, perempuan atau wanita mempunyai peran ganda dalam pekerjaan, hal tersebut bisa dinilai positif selama tujuannya untuk menambah pendapatan keluarga, mengisi waktu luang dan mengembangkan kemampuan diri agar berprestasi, oleh karenanya peran ganda tersebut dibenarkan dan perlu dilestarikan (Zainal, 1992 dalam supriyati, 2012). Sebelum melakukan pembelian lahan, petani 
mengutamakan untuk membeli lahan rumah tangga petani yaitu membangun yang nantinya akan didirikan rumah, rumah dari hasil uang remitansi (Tabel membeli kendaraan, serta membiayai 1).

sekolah anak. Sebagian besar keinginan

Tabel 1. Pengunaan Remitansi Oleh Petani

\begin{tabular}{cl}
\hline No. & \multicolumn{1}{c}{ Penggunaan Remitansi } \\
\hline 1. & Membangun Rumah \\
2. & Kebutuhan sehari-hari (makan, biaya sekolah, dan membayar hutang, dan lainnya) \\
3. & Membeli kendaraan \\
4. & Modal untuk musim tanam \\
5. & Membayar hutang \\
6. & Pembelian lahan pertanian (investasi pertanian) \\
\hline
\end{tabular}

Adanya pergeseran status petani yang awalnya sebagai buruh tani kemudian menjadi petani penggarap dan menjadi petani yang sudah memiliki luas lahan lebih dari 1 hektar. Tentunya keinginan buruh tani serta petani penggarap yaitu memiliki lahan pertaniannya sendiri, sehingga mereka merasa kehidupan mereka terjamin karena adanya tanah yang dipergunakan sebagai mata pencaharian. Awal mulanya rumah tangga petani menggunakan uang remitansi yang sudah disimpan oleh pekerja migran perempuan kemudian digabungkan dengan pendapatan kepala rumah tangga petani. Remitansi tersebut menjadi pendapatan tambahan bagi rumah tangga petani. Akibatnya dapat dengan mudah mengakses kebutuhan sehari-hari, seperti pangan serta adanya ketertarikan pada barang-barang tersier seperti kendaraan.
Hal tersebut sejalan dengan pemikiran yang diungkapkan oleh Purwaningsih, dkk. (2014 dalam fatimah, 2018) tingginya pendapatan rumah tangga maka daya belinya akan tinggi juga dan rumah tangga semakin mudah mengakses pangan. Selanjutnya, uang tersebut dipergunakan untuk mengadai sawah dan tidak dapat dibayar kembali oleh pemilik sawah yang sah, maka rumah tangga migran membayar sawah tersebut dengan perhitungan yang sudah disepakati kedua belah pihak (pengadai sawah dan pemilik sawah). Tentunya untuk dapat melakukan investasi sawah seperti pembelian ataupun gadai, melalui proses yang panjang dan biaya yang tidak sedikit. Investasi di bidang pertanian tentunya bisa terlaksana, apabila rumah tangga petani tidak menjadikan remitansi sebagai penghasilan utama dan kepala rumah tangganya harus tetap bekerja. 
Kontribusi remitansi pada rumah tangga petani terjadi di Desa Dadap, salah satunya dipergunakan untuk pembelian sawah atau gadai sawah. Penghasilan kepala rumah tangga petani di gabungkan dengan remitansi ekonomi dari pekerja migran perempuan (istri). Perilaku rumah tangga di Desa Dadap, pendapatan suami dan istri tidak dapat dipisahkan, keduanya melebur menjadi satu. Berikut ini Tabel 2. mengenai kontribusi remitansi ekonomi.

Tabel 2. Kontribusi Remitansi Pada Investasi Pembelian Lahan

\begin{tabular}{cccc}
\hline No. & Pendapatan & Investasi pembelian lahan/ 5 bulan & Persentase \\
\hline 1. & Suami (petani) & Rp 17.500 .000 & $46,6 \%$ \\
2. & Istri (pekerja migran) & $R p ~ 20.000 .000$ & $53,4 \%$ \\
\hline \multicolumn{2}{c}{ Jumlah } & Rp 37.500.000 & $\mathbf{1 0 0 \%}$ \\
\hline
\end{tabular}

Pendapatan AD selama lima bulan dari hasil bertani di sawah miliknya. Nominal sebesar Rp 17.500.000 sudah merupakan jumlah pendapatan yang disisihkan untuk investasi pembelian lahan sawah. Pengeluaran rumah tangga petani AD selama lima bulan yaitu $R p$ 7.500.000, pendapatan kotornya selama lima bulan yaitu Rp 25.000.000. Pada mulanya $\mathrm{AD}$ melakukan gadai sawah sejak tahun 1996, besarnya nominal yang dibayarkan tergantung dari kesepakatan kedua pihak. ${ }^{2}$ Seiring berjalannya waktu, sawah yang di gadai akhirnya bisa dibeli. Sampai saat ini total sawah yang dimiliki sekitar 1,5 ha. luas lahan milik AD yang sudah dimiliki lebih dari 0,8 ha berarti luas lahan tersebut masuk dalam kategori luas. Hal tersebut sesuai dengan pengelompokan lahan menurut

\footnotetext{
${ }^{2}$ Wawancara dengan AD 22 September 2019.
}

Soekartawi (1989 dalam fatimah, 2018) yang terbagi menjadi tiga kategori yaitu sempit (<0,5 ha), sedang (0,5-0,8 ha), dan luas (.0,8 ha). Pengelolaan keuangan rumah tangga yang baik, maka akan menghasilkan mangfaat yang baik bagi rumah tangga petani tersebut, sehingga dapat lahir investasi di bidang pertanian. Namun, sebelum adanya kontribusi dari pekerja migran perempuan, keuangan rumah tangga petani mengalami banyak kekurangan. Pengeluaran lebih besar dari pada pendapatan kepala rumah tangga petani. Ketika mengalami gagal panen, sejalan dengan hal tersebut petani mengalamin penurunan pendapatan. Adanya penghasilan yang rendah mendorong petani untuk mencari jalan lain tambahan penghasilan agar kebutuhan rumah tangganya dapat terpenuhi. Menurut Sumarti (2007 dalam Sugiharto, 2016 dalam Nuraisah, 2019) 
upaya yang dilakukan petani dapat berupa menjalani pola nafkah ganda. Sebagian petani biasanya bekerja juga di sektor kelautan (nelayan), menjadi tukang ojek atau berdagang. Hal tersebut dilakukan karena, banyaknya kebutuhan hidup yang harus dipenuhi seperti, biaya kebutuhan sehari-hari (makan, rokok, dan dan biaya sekolah anak) serta jumlah tanggungan.
Hal tersebut sejalan dengan pendapat Arida dkk. (2015 dalam Fatimah, 2018) bahwa semakin banyaknya tanggungan keluarga akan membutuhkan biaya yang lebih besar sehingga pengeluaran juga semakin besar. Untuk lebih jelasnya perhatikan Tabel 3.

Tabel 3. Perekonomian Rumah Tangga Petani Sebelum Adanya Remitansi

\begin{tabular}{llcc}
\hline No. & \multicolumn{1}{c}{ Jenis Pengeluaran } & Pengeluaran/ bulan & Pendapatan/ bulan \\
\hline 1. & Makan & Rp 900.000 & Rp 500.000 \\
2. & Uang sekolah Satu Orang Anak & Rp 900.000 & sampai Rp 1.500 .000 \\
3. & Rokok & Rp 750.000 & Rp 500.000 - Rp 1.500.000 \\
\hline \multicolumn{2}{c}{ Jumlah }
\end{tabular}

Sumber: Analisis Data Primer (2019)

Tabel 3 merupakan gambaran umum perekonomian rumah tangga petani di Desa Dadap. Perlu digaris bawahi, bahwa tidak setiap hari kepala rumah tangga mendapatkan upah dari bekerja sebagai nelayan, buruh tani atau petani. Adanya kendala bekerja di sektor kelautan dan pertanian. Menurut Arida dkk. (2015 dalam Fatimah, 2018) pendapatan rumah tangga merupakan sejumlah uang yang diperoleh dari pekerjaan dalam satu bulan. Hal tersebut membuat pendapatan rumah tangga petani tidak menentu. Jalan pintas sebelum adanya remitansi, yaitu berhutang. Kepala rumah tangga tidak mampu untuk membayar hutang, mendorong perempuan untuk menjadi pekerja migran. Oleh karena itu, diperlukan adanya kontribusi remitansi untuk membantu perekonomian rumah tangga petani.

Remitansi juga berkontribusi pada rumah tangga petani di sektor kelautan, contohnya investasi untuk pembelian perahu. Sama seperti kehidupan para petani, tentunya remitansi ekomnomi dipergunakan nelayan untuk memenuhi kebutuhan hidup sehari-hari, biaya sekolah anak, membayar hutang, membeli kendaraan, membangun rumah dan cita-cita para nelayan yaitu memiliki perahunya sendiri. Masih banyak nelayan yang belum memiliki perahu sehingga 
mereka hanya ikut berlayar dengan perahu milik orang lain (buruh nelayan). Hal tersebut menyebabkan pendapatan nelayan perharinya berkisar $\mathrm{Rp} 50.000$ sampai Rp 150.000, tentunya jika mereka pergi melaut. Menurut Kusnandi (2003 dalam Kusumaningrum, 2013) bahwa sistem bagi hasil atau pemasaran hasil dari tangkapan, menempatkan para pemilik perahu atau pedagang pelantara atau pedagang ikan memperoleh bagian yang lebih besar dari kegiatan tersebut, hal tersebut dianggap sebagai suatu kewajaran. Kondisi perekonomian nelayan dan petani sebelum adanya remitansi tidak jauh berbeda pendapatan dan pengeluarannya. Adanya remitansi yang berkontribusi untuk pembelian perahu, untuk lebih jelasnya perhatikan Tabel 5.

Tabel 4. Kontribusi Investasi Pada Rumah Tangga Nelayan

\begin{tabular}{cccc}
\hline No. & \multicolumn{1}{c}{ Pendapatan } & Investasi Pembelian Perahu/ bulan & Persentase \\
\hline 1. & Suami (nelayan) & Rp 3.000 .000 & $33,33 \%$ \\
2. & Istri (pekerja migran) & Rp 6.000 .000 & $66,67 \%$ \\
\hline & Jumlah & Rp 9.000 .000 & $100 \%$
\end{tabular}

Sumber: Diolah dari Data Pribadi Informan AR (2019)

Berdasarkan Tabel 5. Adanya remitansi yang berkontribusi pada nelayan. Jumlah investasi yang tercantum tidak selalu besarnya sama setiap bulannya, tergantung dari penghasilan kepala rumah tangga. Upah pekerja migran perempuan yang bekerja di Taiwan sebesar $\mathrm{Rp}$ 7.500.000, tiap bulannya rutin dikirimkan untuk rumah tangga migran. Kebutuhan perbulannya yaitu Rp 1.500.000, sisa Rp 6.000.000 yang dipergunakan untuk investasi pembelian perahu. Harga sebuah perahu berkisar Rp 55.000.000. AR sudah memiliki dua buah perahu dari kontribusi istrinya yang menjadi pekerja migran perempuan di Taiwan.

\section{KESIMPULAN DAN SARAN}

\section{Kesimpulan}

1. Istri menjadi pekerja migran perempuan di Desa Dadap disebabkan oleh tidak menentunya pendapatan suami yang bekerja sebagai nelayan dan petani.

2. Adanya kontribusi remitansi untuk investasi rumah tangga migran di Desa Dadap Kecamatan Juntiyuat Kabupaten Indramayu. Khususnya dilakukan oleh rumah tangga pertanian, yaitu uang remitansi dipergunakan untuk gadai sawah dan membeli sawah. Namun, hanya beberapa orang yang melakukan hal tersebut. investasi pertanian 


\begin{abstract}
menggunakan uang remitansi merupakan tujuan bersama serta kesepakatan pekerja migran perempuan dan anggota rumah tangga migran. Adanya pendapatan kepala rumah tangga dan remitansi ekonomi pekerja migran perempuan yang menjadi satu, kemudian dimanfaatkan ke arah produktif (investasi).
\end{abstract}

\section{Saran}

Rumah tangga petani melakukan diversifikasi usaha pada sektor on farm, off farm dan non farm, sebagai pekerjaan utama atau sebagai pekerjaan sampingan. Contohnya petani di Desa dadap selain bertani juga dapat melakukan penyewaan alat-alat pertanian, petani pemilik lahan juga bisa menyewakan lahannya kepada petani penggarap, dan membuat usaha pembuatan ikan asin atau kerupuk kulit.

\section{DAFTAR PUSTAKA}

BNP2TKI. (2017). Data Penempatan dan Perlindungan TKI.

BPS. (2018). Kabupaten Indramayu dalam Angka 2018.

Fatimah, N., \& Syamsiah, N. (2018). Proporsi Pengeluaran Rumah Tangga Petani Padi di Desa Patimban Kecamatan Pusakanagara, Kabupaten Subang, Jawa Barat. Jurnal Pemikiran Masyarakat Ilmiah berwawasan Agriisnis, 4(2), 184-196.

Irawaty, T., \& Wahyuni, E. sri. (2011). Migrasi Internasional Perempuan
Desa dan Pemanfaatan Remitansi di Desa Pusakajaya, Kecamatan Pusakajaya, Kabupaten Subang, Provinsi Jawa Barat. Jurnal Transdisiplin Sosiologi, Komunikasi, dan Ekologi Manusia, 05(03), 297-310.

Kusumaningrum, A. (2013). Kebijakan pembangunan Dalam pengentasa Kemiskinan Masyarakat Pesisir (Studi Kasus pada Masyarakat Pesisir di Kabupaten Purworejo , Jawa Tengah). Agriekonomika, 2(1), 13-26.

Ma'arif, S. (2018). Pemanfaatan Dana remitansi Tenaga Kerja Indonesia di Kabupaten Indramayu Tahun 2012-2016. 3(1), 22-42.

Miles, M. B., \& Huberman, A. M. (1992). Analisis Data Kualitatif. Jakarta: Universitas Indonesia.

Moleong, lexy J. (2017). Metodologi penelitian Kualitatif. Bandung: PT Remaja Rosdakarya.

Mustapita, A. F., \& Rizal, M. (2017). Analisis pola penggunaan remitan migrasi internasional secara produktif dan konsumtif di kabupaten malang. 1(2), 6-10.

Nuraisah, G., \& Kusumo, R. A. B. (2019). Dampak Perubahan Iklim Terhadap Usaha Tani Padi di Desa Wanguk Kecamatan Anjatan Kabupaten Indramayu. Jurnal Pemikiran Masyarakat Ilmiah berwawasan Agriisnis, 5(1), 60-71.

Putra, M. A. jaya, Chadijah, R., \& Warsito, H. (2017). Remitansi dan Pemanfaatannya Terhadap Kehidupan Sosial Ekonomi Keluarga: Studi Kasus Desa Seriguna Kecamatan Teluk Gelam Oki. 1-14.

Supriyati. (2012). Persepsi dan Sikap Wanita Tani terhadap Agroindustri Pangan di Kabupaten Bantul. Agriekonomika, 1(1), 68-76. 